\title{
Simple automated method for urinary creatinine estimation
}

\begin{abstract}
A. H. BITTLES, J. F. BELL, and D. W. NEILL From the Biochemistry Departments, Royal Victoria Hospital, Belfast, and Belfast City Hospital
\end{abstract}

The increasing numbers of investigations into metabolic processes have necessitated the adaptation to automated principles of a method whereby the efficacy of quantitative urine collections can be tested. The estimation of creatinine (creatine anhydride) for this purpose has several advantages over other methods which have been used.

Creatinine excretion is fairly constant from day to day (Folin, 1914; Shaffer, 1914), being independent of muscular activity, urine volume, and the state of nitrogen metabolism of the body. Creatinine is a waste product endogenously derived from creatine and its level of excretion is influenced by the diet only when the diet contains significant quantities of creatine or creatinine, for example, in a heavy fish or meat meal. When preformed creatinine is administered to normal subjects it is rapidly and almost wholly excreted. Thus, it can be seen that if marked variations in urinary creatinine levels are observed which do not correspond to muscular development or breakdown, or to changes in the diet involving preformed creatinine, it can be assumed that there has been some error in the collection of urine specimens.

The main criteria of the method for urinary creatinine estimation were that it should be rapid, accurate, and basically simple in both design and operation. The method which has been evolved is operated at a rate of 60 estimations per hour, can estimate specimens containing creatinine concentrations of $0-200 \mathrm{mg} . / 100 \mathrm{ml}$., and is based on the Jaffé (1886) reaction.

The Jaffé reaction takes place when creatinine is mixed with alkaline picrate solution giving rise to the formation of the red tautomer of creatinine picrate (Greenwald and Gross, 1924; Greenwald, 1925, 1928). The known lack of specificity of the reaction for plasma has not been held to invalidate its use in urine estimations. The coloured product formed obeys Beer's law for monochromatic

Received for publication 24 April 1964. light (Hervey, 1953) and at specific wavelengths (Clark and Thompson, 1949) but does not obey Beer's law when the colour is measured using a filter colorimeter. The amount of colour produced due to creatinine is greatest at low concentrations of alkali and is independent of picric acid concentration above a low limiting value. Colour development is more rapid at higher concentrations of both alkali and picric acid (Bonsnes and Taussky, 1945).

The amount of colour produced is both temperature and $p \mathrm{H}$ dependent, and since the creatine-creatinine equilibrium in the urine can be upset by both hydrogen and hydroxyl ions, it is inadvisable to use either acid or alkali for urine preservation (Taussky, 1956).

\section{REAGENTS}

DISTILled WATER AND $\frac{1}{4}$ SATURATED PICRIC ACID Place approximately $13 \mathrm{~g}$. of purified picric acid (Hawk, Oser, and Summerson, 1954) in a 1 litre flask and add distilled water up to the mark. Mix thoroughly for several hours, filter and dilute $250 \mathrm{ml}$. of the $\frac{1}{4}$ saturated picric acid to 1 litre with distilled water.

\subsection{NORMAL SODIUM HYDROXIDE}

CREATININE STANDARD Creatinine zinc chloride, 3.204 g., is made up in 1 litre of $0 \cdot 1 \mathrm{~N} \mathrm{HCl}$. This gives a concentration of $2 \mathrm{mg}$. $/ \mathrm{ml}$. as creatinine. Dilutions are made with $\mathbf{0} \cdot 1$ normal $\mathrm{HCl}$ to give concentrations corresponding to $25,50,75,100,125,150$, and $175 \mathrm{mg} . / 100 \mathrm{ml}$.

\section{METHOD}

The urine sample is diluted with distilled water and segmented with air, then mixed in a single coil. The alkaline picrate reagent is introduced into the diluted sample stream and the diluted urine and alkaline picrate reagent mixed in a double coil. The reaction mixture is then led into a $37^{\circ} \mathrm{C}$. water bath where colour is produced and thence into the colorimeter to be read at $505 \mathrm{~m} \mu$. The general arrangement follows standard AutoAnalyzer practice (AutoAnalyzer technical manuals, 1962) and is set out in Figure 1.

\section{RESULTS}

This adaptation of the Jaffé reaction is independent of urinary $p \mathrm{H}$ change between $p \mathrm{H} 3$ and $p \mathrm{H} 8.5$ and since the colour production is carried out in a $37^{\circ} \mathrm{C}$. water bath it is not affected by changes in room temperature.

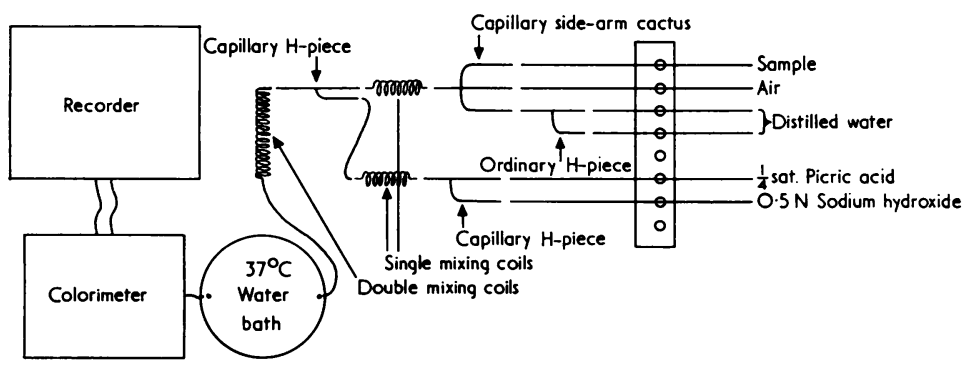

FIG. 1. Tube sizes (internal diameter):- Sample 0.030 in., air 0.056 in., distilled water 0.081 in., picric acid 0.035 in., and sodium hydroxide 0.035 in. 
Recovery experiments (Table I) showed a mean recovery of $97 \%$ of creatinine added over a wide range of concentrations. The presence of urinary protein up to a concentration of $5 \mathrm{~g}$. per litre is without significant effect on the measured creatinine level (Table II).

TABLE I

RESULTS OF RECOVERY EXPERIMENTS

\begin{tabular}{|c|c|c|c|c|}
\hline $\begin{array}{l}\text { Initial } \\
\text { Creatinine } \\
\text { Concentra- } \\
\text { tion of Urine } \\
(\mathrm{mg} . / 100 \mathrm{ml} .)\end{array}$ & $\begin{array}{l}\text { Amount of } \\
\text { Creatinine } \\
\text { Added } \\
(\text { mg./100 } \\
\text { ml. })\end{array}$ & $\begin{array}{l}\text { Expected } \\
\text { Results } \\
\text { (mg./100 } \\
\text { ml.) }\end{array}$ & $\begin{array}{l}\text { Observed } \\
\text { Result } \\
\text { (mg./100 } \\
\text { ml.) }\end{array}$ & $\begin{array}{l}\text { Percentage } \\
\text { Recovery }\end{array}$ \\
\hline 50 & $\begin{array}{l}0.15 \\
0.30 \\
0.45 \\
0.60 \\
0.75 \\
0.90 \\
1.05 \\
1.20 \\
1.35\end{array}$ & $\begin{array}{r}65 \\
80 \\
95 \\
110 \\
125 \\
140 \\
155 \\
170 \\
185\end{array}$ & $\begin{array}{l}65 \cdot 5 \\
79 \\
92 \cdot 5 \\
106 \\
121 \\
137 \\
152 \cdot 5 \\
169 \\
183\end{array}$ & $\begin{array}{r}103 \\
97 \\
95 \\
93 \\
95 \\
97 \\
98 \\
99 \\
99\end{array}$ \\
\hline
\end{tabular}

TABLE II

EFFECT OF URINARY PROTEIN ON OBSERVED LEVELS OF CREATININE

\begin{tabular}{cc} 
Urine Protein $(\mathrm{g}$. per litre $)$ & Creatinine $(\mathbf{m g} . / 100 \mathrm{ml})$. \\
\hline 0 & 104 \\
$1 \cdot 0$ & 104 \\
$2 \cdot 0$ & 104 \\
$3 \cdot 0$ & 104 \\
$4 \cdot 0$ & 105 \\
$5 \cdot 0$ & 106
\end{tabular}

The mean and standard deviations of the method were calculated from the results obtained by estimating a single urine sample 50 times. The mean deviation for the method was \pm 1.19 and the standard deviation $\pm 1.09 \mathrm{mg} . / 100 \mathrm{ml}$.

The creatinine concentrations obtained for 25 normal, male subjects ranged from 1.15 to $2.86 \mathrm{~g}$. $/ 24 \mathrm{hr}$., the volume of urine passed by the 25 subjects in 24 hours varying from 600 to $2,510 \mathrm{ml}$. Corresponding values fe् 50 normal female subjects were from 0.82 to $1.76 \mathrm{~g}$. $/ 2 \mathrm{~g}$ hr. of creatinine excreted. The volumes of the 24-hour collections ranged from 415 to $2,900 \mathrm{ml}$.

\section{SUMMARY}

A rapid, accurate method for urinary creatinine estima tion employing the Technicon AutoAnalyzer is describe $\$$ The method is independent of temperature change and also of variations in $\mathrm{pH}$ in normal urines. The mean deviation of the method is $\pm 1 \cdot 19$, the standard deviation \pm 1.09 , and the percentage recovery $97 \%$ of creatinine added.

The normal values of creatinine excretion for aduiti males are 1.15 to $2.86 \mathrm{~g} . / 24 \mathrm{hr}$. and for normal aduit females 0.82 to $1.76 \mathrm{~g} . / 24 \mathrm{hr}$.

We would like to acknowledge with gratitude, the cooperation and advice given by $\mathrm{Mr}$. G. Welshman in the preparation of this paper.

\section{ADDENDUM}

The new AutoAnalyzer techniques employing the tubula $\vec{b}$ flowcell (AutoAnalyzer methodology sheet No. 11a) caßg also be utilized in this way (Fig. 2).

\section{REFERENCES}

AutoAnalyzer Technical Manuals (1962). Technicon Instruments Co Chertsey, Surrey.

Bonsnes, R. W., and Taussky, H. H. (1945). J. biol. Chem., 158, 58 P

Clark, L. C., and Thompson, H. L. (1949). Analyt. Chem., 21, 1218

Folin, O. (1914). J. biol. Chem., 17, 469.

Greenwald, I. (1925). J. Amer. chem. Soc., 47, 1443.

- (1928). J. biol. Chem., 80, 103.

$\longrightarrow$, and Gross, J. (1924). Ibid., 59, 601. Physiological Chemistry, p. 1330 . Blakiston, New York.

Hervey, G. R. (1953). Nature (Lond.), 171, 1125.

Jaffe, M. (1886). Hoppe-Seylers Z. physiol. Chem., 10, 391.

Shaffer, P. A. (1914). J. biol. Chem., 18, 525.

Taussky, H. H. (1956). Clin. chim. Acta, 1, 210.

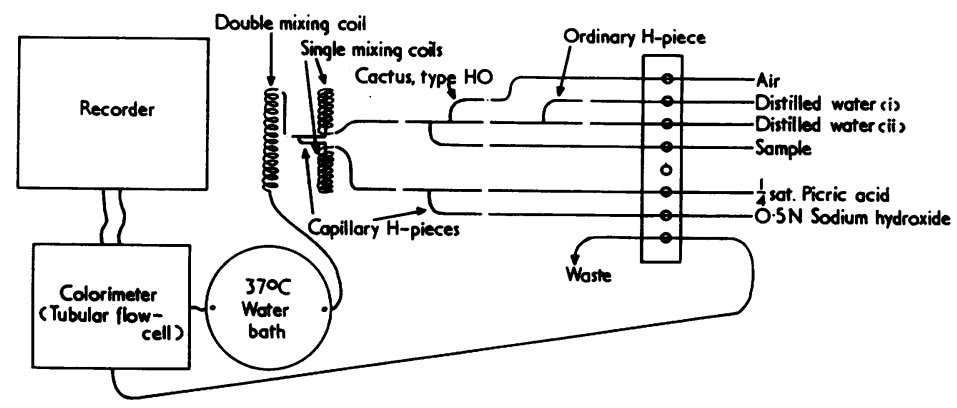

FIG. 2. Urinary creatinine estimation ( $N-$ Methodology). Filters used: $505 \mathrm{m \mu}$. Tube sizes in inches (internal diameter) Air 0.056; distilled water (i) 0.081 ; distilled water (ii) 0.073 sample 0.020 ; picric acid 0.035 ; sodium hydroxide 0.035 ; waste 0.081 . 